von Euler, H. (1932). Ergebn. Physiol. 34, 360.

von Euler, H. \& Klussmann, E. (1932). Hoppe-Seyl. Z. 213, 21.

Wiese, C. E., Mehl, J. W. \& Deuel, H. J. Jr. (1947). Arch. Biochem. 15, 75.

Woolf, B. \& Moore, T. (1932). Lancet, 223, 13.

Worker, N. A. (1956a). Brit. F. Nutr, 1o, 169.

Worker, N. A. (1956b). F. Nutr. 6o, 447 .

Worker, N. A. (1957). Brit. F. Nutr. I1, 44.

\title{
The availability of bound nicotinic acid to the rat
}

\author{
1. The effect of lime-water treatment of maize and \\ subsequent baking into tortilla
}

By E. KODICEK AND P. W. WILSON
Dunn Nutritional Laboratory, University of Cambridge and Medical Research Council

(Received 7 April 1959)

In an earlier paper (Kodicek, Braude, Kon \& Mitchell, I959) the reviewed evidence showed that maize and other cereals contain almost all their nicotinic acid in a bound form which is unlike any of the known nicotinoyl compounds in being unavailable to rats, dogs, poultry or pigs and, probably, man. For the rat or pig the full biological activity of bound nicotinic acid in maize and other cereals can be released by hydrolysis with $0.5 \mathrm{~N}-\mathrm{NaOH}$, which liberates free nicotinic acid (Chaudhuri \& Kodicek, I950; Kodicek, 195I; Harper, Punekar \& Elvehjem, I958; Kodicek et. al. 1956). Maize cooked with lime-water, as in the preparation of tortilla in Central America and particularly in Mexico, has been reported to cure nicotinic-acid deficiency in rats (Laguna \& Carpenter, 195I; Cravioto, Massieu, Cravioto \& Figueroa, 1952; Squibb, Braham, Arroyave \& Scrimshaw, 1955; Massieu, Cravioto, Cravioto, Guzmán \& Suarez Soto, 1956; Fiorentini, Gaddi \& Bonomolo, 1956; Pearson, Stempfel, Valenzuela, Utley \& Darby, 1957). Kodicek et al. (1959) showed that such treatment of maize releases the full biological activity of nicotinic acid for the pig. However, two other research groups did not observe a curative effect of maize treated with limewater on either rats (Krehl, Henderson, de la Huerga \& Elvehjem, 1946) or man (Goldsmith, Rosenthal, Gibbens \& Unglaub, 1955; Goldsmith, Gibbens, Unglaub $\&$ Miller, 1956). The negative results obtained by the latter group appear to have been due mainly to the small amount of maize in the diet, which would not have contributed significantly to the supply of nicotinic acid even if it had been completely available. Other factors may, however, contribute to the success or failure of lime-water treatment, particularly variations in the method of preparing tortilla, which may determine the extent to which nicotinic acid is liberated.

We have, therefore, re-investigated the lime-water procedure in detail and tested various tortilla preparations, both biologically on nicotinic-acid deficient rats and 
microbiologically or chemically, in search of such differences as might lead to discrepant results. The original method of preparing Mexican tortilla described by Cravioto, Anderson, Lockhart, Miranda \& Harris (1945) was represented by two samples, one prepared in this laboratory from yellow Plate Argentinian maize and the other supplied by Dr R. O. Cravioto direct from Mexico. They were compared with a commercial preparation (masa harina) kindly supplied by The Quaker Oats Co. of Chicago. In masa harina the maize treated with lime-water had been washed with water, so that the $\mathrm{pH}$ of the sample was lowered to $7 \cdot 6$, and exposed to heat for a few seconds. Two additional samples of material were tested, namely gluten feed hydrolysed with either $\mathrm{I} \%$ or $0.1 \%$ lime-water and neutralized before drying in the oven.

\section{EXPERIMENTAL}

\section{Analytical methods}

Total nicotinic acid was estimated chemically by extracting the materials with ○. I N-HCl by the method of Kodicek \& Pepper (1948). The extracts were hydrolysed with $2 \mathrm{~N}-\mathrm{HCl}$ for $2 \mathrm{~h}$ at $100^{\circ}$, the $\mathrm{pH}$ was then brought to $2 \cdot 8$; the extracts were washed with half their volume of isobutanol saturated with water. The solution was placed on a boiling water-bath to evaporate the dissolved isobutanol, cooled and acidified further with 8 drops conc. $\mathrm{HCl}$. The acidified extract was oxidized with permanganate solution (Wang \& Kodicek, 1943), the $\mathrm{pH}$ brought to 6.8 and the volume adjusted with water and $98 \%$ ethanol to give a final concentration of $30 \%$ ethanol. After centrifuging, the colorimetric estimation with the cyanogen-bromide- $p$-aminoacetophenone reagent was done by the method of Wang \& Kodicek (1943). Microbiologically, nicotinic acid was estimated with Lactobacillus casei ATCC 7469 by the method of Clegg, Kodicek \& Mistry (1952). The bound and free nicotinic acid were distinguished by the difference in the response of $L$. casei to hydrolysed and unhydrolysed extracts of the material (Clegg et al. 1952). The unhydrolysed extracts contained the bound nicotinic acid originally present, which is only partly available to $L$. casei under the conditions of the microbiological test. Since that procedure gave only a semi-quantitative indication of the presence or absence of free nicotinic acid, the latter was estimated chromatographically by preparing extracts as described by Kodicek et al. (1956), with some modifications: the extracts were prepared by refluxing $10 \mathrm{~g}$ of the material twice with $40 \mathrm{ml} 80 \%(\mathrm{v} / \mathrm{v})$ methanol for $\mathrm{I} h$ and not with methanol containing O.I N-HCl. The extracted residue was washed twice with $20 \mathrm{ml} 80 \%$ methanol. The combined extracts and washings were left standing at 4 for $\mathrm{I} \mathrm{h}$ and centrifuged and the residue was re-extracted with $10 \mathrm{ml} 80 \%$ methanol. The combined extracts which, according to our estimation, contained $100 \%$ of the original nicotinic acid, were evaporated at $70^{\circ}$ under reduced pressure to a small volume ( $12 \mathrm{ml}$ ) and centrifuged. The supernatant liquid was then evaporated to dryness and taken up in $2 \mathrm{ml}$ water, the undissolved residue was extracted with $2 \mathrm{ml} 70 \%(\mathrm{v} / \mathrm{v})$ ethanol. The volume of the combined extracts was adjusted to $4 \mathrm{ml}$, and portions of 20,40 , 60 and $80 \mu 1$ were used for paper chromatography. The chromatograms, developed with $\mathrm{n}$-butanol saturated with water, were exposed to cyanogen-bromide vapour and 
sprayed with $2 \% p$-aminobenzoic acid reagent (Kodicek $\&$ Reddi, I95 I). The resulting yellow fluorescent spots were matched visually with standards of the appropriate strength $(0.25,0.50,0.75$ and $\mathrm{I} \cdot 0 \mu \mathrm{g}$ nicotinic acid $)$ run side by side with the unknown, as described by Reddi \& Kodicek (I953).

Tryptophan was estimated chemically by the method of Graham, Smith, Hier \& Klein (I947). The $\mathrm{pH}$ of the maize preparations was measured electrometrically with a $\mathrm{pH}$ meter (Marconi and Co. Ltd) in suspensions of $\mathrm{I} g$ of material in $5^{\circ} \mathrm{ml}$ distilled water. The crude protein of the materials was calculated from their nitrogen content, determined by the Kjeldahl method, the factor $6 \cdot 25$ being used.

\section{Treatment of maize preparations}

Tortilla prepared at the Dunn Nutritional Laboratory (D.N.L. tortilla). The limewater treatment of yellow Plate Argentinian maize to prepare tortilla was done by the original Mexican procedure (Cravioto et al. I945; Cravioto, Cravioto, Huerta, Guzmán, Massieu \& Calvo de la Torre, 1950), as described in Table 5 of the earlier paper (Kodicek et al. 1959); it involved overnight soaking of the kernels in water, boiling for $20 \mathrm{~min}$, decanting of the supernatant liquid, subsequent heating of the residue with $\mathrm{I} \%$ lime-water for $\mathrm{I} h$ at $80^{\circ}$ and standing overnight. Then a small amount of water was added and, after mixing, the supernatant liquid was poured off; the cooked maize was mashed, formed into flat cakes and baked for $15 \mathrm{~min}$ on girdles. The resulting tortilla was then dried at $70^{\circ}$, ground and given to animals in the diets to be described.

Table 1. Effect of lime-water treatment and subsequent baking on liberation of bound nicotinic acid in maize

$\begin{array}{lcc}\text { Maize preparation } & \begin{array}{c}\text { Unhydrolysed } \\ \text { extract* } \\ \text { Microbiological } \\ \text { test }\end{array} & \begin{array}{c}\text { Hydrolysed extract } \\ \text { (total nicotinic acid) } \\ \text { Microbiological } \\ \text { test }\end{array} \\ \begin{array}{l}\text { Maize, Plate Argentinian, yellow } \\ \text { Maize, treated with I \% lime- }\end{array} & 6.3 & 19.5 \\ \text { water (mash) } & 7.5 & 10.2 \\ \text { Tortilla } & 9.8 & 9.5\end{array}$

* Bound nicotinic acid has only $30-50 \%$ biological activity for $L$. casei under the conditions of the microbiological test (Clegg et al. 1952).

In preliminary experiments (Table $\mathrm{I}$ ) it was established that boiling with $\mathrm{I} \%$ limewater for $\mathrm{I} h$ did not necessarily liberate the entire bound nicotinic acid and that liberation was completed in the subsequent baking of the alkaline mash. On the other hand, in the large-scale preparation of tortilla reported earlier (Kodicek et al. 1959) almost all the nicotinic acid was liberated on boiling with lime-water; the cooked mash contained $4.3 \mu \mathrm{g}$ free and $5.2 \mu \mathrm{g}$ total nicotinic acid/g wet weight. The material from the large-scale preparation naturally needed a longer time to cool down and had a slightly longer treatment in lime-water than the small-scale samples. In the pre- 
liminary trial with smaller batches (see Table 6 in the paper of Kodicek et al. 1959), in which the temperature treatment was purposely prolonged to simulate the largescale preparation, we had found complete splitting of the bound nicotinic acid; the resulting mash had $3.2 \mu \mathrm{g}$ free and $3.2 \mu \mathrm{g}$ total nicotinic acid/g wet weight. In the D.N.L. tortilla used in the present experiments all the nicotinic acid was liberated and the product was distinctly alkaline, $\mathrm{pH}$ IO. I (Tables 2 and 3 ). Only a small loss of nicotinic acid occurred and the amount lost was found in the discarded liquors $(2 \cdot 9 \mu \mathrm{g}$ nicotinic acid/g of the original maize).

Table 2. Nicotinic-acid content $(\mu \mathrm{g} / \mathrm{g})$ of constituents of diets

\begin{tabular}{|c|c|c|c|c|}
\hline \multirow[b]{2}{*}{ Constituent* } & \multirow{2}{*}{$\begin{array}{l}\text { Unhydrolysed } \\
\text { extract } † \\
\text { Microbiological } \\
\text { test }\end{array}$} & \multicolumn{3}{|c|}{$\begin{array}{l}\text { Hydrolysed extract } \\
\text { (total nicotinic acid) }\end{array}$} \\
\hline & & $\begin{array}{c}\text { Microbiological } \\
\text { test }\end{array}$ & $\begin{array}{l}\text { Chemical } \\
\text { test }\end{array}$ & Mean \\
\hline Untreated maize meal & $9 \cdot 7$ & $17 \cdot 7$ & $20 \cdot 6$ & $19 \cdot 2$ \\
\hline Untreated Argentinian maize & $6 \cdot 3$ & 19.5 & $17 \cdot 0$ & $18 \cdot 3$ \\
\hline D.N.L. tortilla & $15 \cdot 8$ & $16 \cdot 9$ & $16 \cdot 2$ & 16.37 \\
\hline Untreated Mexican maize & $6 \cdot 0$ & $15 \cdot 7$ & $13 \cdot 6$ & $14 \cdot 7$ \\
\hline Mexican tortilla & $9 \cdot 4$ & $9 \cdot 7$ & $9 \cdot 3$ & $9 \cdot 5$ \\
\hline Untreated U.S.A. maize & $6 \cdot 7$ & $13 \cdot 1$ & - & $13^{*} \mathbf{I}$ \\
\hline Masa harina & $6 \cdot 3$ & $12 \cdot 9$ & 一 & $12 \cdot 9$ \\
\hline Tortilla from masa harina & $9 \cdot 0$ & 13.9 & 一 & 13.9 \\
\hline $\begin{array}{l}\text { Tortilla from masa harina, alkali- } \\
\text { hydrolysed }\end{array}$ & $15 \cdot 2$ & 13.9 & - & $14 \cdot 6 t$ \\
\hline $\begin{array}{l}\text { Gluten feed, treated with I \% lime- } \\
\text { water }\end{array}$ & $27 \cdot 4$ & $42 \cdot 6$ & $41 \cdot 6$ & $42 \cdot I$ \\
\hline $\begin{array}{l}\text { Gluten feed, treated with } 0.1 \% \text { lime- } \\
\text { water }\end{array}$ & $12 \cdot 3$ & $35^{\circ} \circ$ & $34^{\circ} 7$ & $34^{*} 9$ \\
\hline Casein, 'vitamin-free' (Genatosan Ltd) & 3.5 & 3.5 & $\longrightarrow$ & $3 \cdot 5$ \\
\hline
\end{tabular}

* D.N.L. tortilla, prepared at the Dunn Nutritional Laboratory from yellow Plate Argentinian maize treated with I \% lime-water and baked by the method of Cravioto et al. (I945); Mexican tortilla, received from Mexico; masa harina, commercial preparation of maize treated with lime-water and supplied as flour by The Quaker Oats Co., Chicago; tortilla from masa harina, baked by us from masa harina; tortilla from masa harina, alkali-hydrolysed, treated with $0.3 \mathrm{~N}-\mathrm{NaOH}$ for $45 \mathrm{~min}$, neutralized and dried, corrected for $12 \%$ salt content; gluten feed, treated with lime-water, neutralized and dried (see p. 422).

$\dagger$ Bound nicotinic acid has only $30-50 \%$ biological activity for $L$. casei under the conditions of the microbiological test (Clegg et al. I952).

$\ddagger$ Mean value for unhydrolysed and hydrolysed extracts; all nicotinic acid in the free form.

Mexican tortilla. It can be seen from Tables 2 and 3 that in the Mexican tortilla all the nicotinic acid, $9.5 \mu \mathrm{g} / \mathrm{g}$, was in free form and the preparation was alkaline, $\mathrm{pH} \mathrm{8.8,} \mathrm{whereas} \mathrm{the} \mathrm{maize} \mathrm{from} \mathrm{which} \mathrm{it} \mathrm{had} \mathrm{been} \mathrm{prepared} \mathrm{contained} 14.7 \mu \mathrm{g}$ nicotinic acid/g, $98 \%$ in bound form. The loss of nicotinic acid $(35 \%)$ was greater than in the D.N.L. tortilla, possibly because more of the washing liquors had been discarded.

Masa harina. The material was prepared by a patented process which includes the usual treatment with I \% lime-water, washing to reduce the alkalinity to $\mathrm{pH} 8$ and quick drying $(20 \mathrm{sec})$ by a blast of hot air during grinding to produce the flour (masa harina).

It will be seen from Tables 2 and 3 that the final product was only slightly alkaline, $\mathrm{pH} 7 \cdot 6$, and had most of its nicotinic acid in bound form. That finding, based on 
microbiological assay, was confirmed by paper chromatography. Tortilla prepared in this laboratory from masa harina, by the usual technique of baking flat cakes on a girdle, still had most of its nicotinic acid in bound form. In order to show that this bound nicotinic acid could be released, the baked preparation was treated with $0.3 \mathrm{~N}-\mathrm{NaOH}$ for $45 \mathrm{~min}$ at $90^{\circ}$, the suspension being neutralized and dried at $70^{\circ}$; the values shown in Table 2 indicate a complete freeing of bound nicotinic acid.

\section{Table 3. Free and bound nicotinic acid, tryptophan, and crude protein} in constituents of diets

\begin{tabular}{|c|c|c|c|c|c|}
\hline \multirow[b]{2}{*}{ Constituent } & \multirow[b]{2}{*}{$\mathrm{pH}$} & \multicolumn{2}{|c|}{$\begin{array}{l}\text { Nicotinic acid* } \\
(\mu \mathrm{g} / \mathrm{g})\end{array}$} & \multirow{2}{*}{$\begin{array}{l}\text { Tryptophan } \\
\text { (mg/g) }\end{array}$} & \multirow{2}{*}{$\begin{array}{l}\text { Crude } \\
\text { protein } \\
(\mathrm{mg} / \mathrm{g})\end{array}$} \\
\hline & & Free & Bound & & \\
\hline Untreated maize meal & $6 \cdot 2$ & $0 \cdot 3$ & I8.9 & 0.75 & 85 \\
\hline Untreated Argentinian maize & $6 \cdot 3$ & 0.3 & I $8 \cdot 0$ & I.08 & 85 \\
\hline D.N.L. tortilla & $10 \cdot 1$ & $16 \cdot 3$ & $\circ$ & I.08 & 85 \\
\hline Untreated Mexican maize & $6 \cdot 6$ & $0 \cdot 3$ & $14 \cdot 4$ & $1 \cdot 00$ & 102 \\
\hline Mexican tortilla & $8 \cdot 8$ & $9 \cdot 5$ & 0 & $\mathrm{I} \cdot 08$ & 102 \\
\hline Masa harina & $7 \cdot 6$ & $1 \cdot 0$ & II $\cdot 9$ & $1 \cdot 15$ & 88 \\
\hline Tortilla from masa harina & $7 \cdot 6$ & $3 \cdot 0$ & 10.9 & $1 \cdot 15$ & 88 \\
\hline Gluten feed, treated with I \% lime-water & $6 \cdot 8$ & $8 \cdot 5$ & $33 \cdot 6$ & $1 \cdot 12$ & 285 \\
\hline Gluten feed, treated with $0.1 \%$ lime-water & $6 \cdot 0$ & 0.6 & $34 \cdot 3$ & $I \cdot 17$ & 285 \\
\hline Casein, 'vitamin-free' (Genatosan Ltd) & - & $3 \cdot 5$ & 0 & $12 \cdot 00$ & 915 \\
\hline
\end{tabular}

* Values are means of chemical and microbiological estimations (see Table 2). Analysis by paper chromatography showed free nicotinic acid, derived from the germ, in untreated maize and in gluten feed treated with $0.1 \%$ lime-water and, derived from partial liberation of bound nicotinic acid, in masa harina and tortilla from masa harina and in gluten feed treated with $1 \%$ lime-water.

Gluten feed. It was intended to use maize bran, which is by far the richest source of nicotinic acid among the components of maize grain (Heathcote, Hinton \& Shaw, I952), and to replace part of the maize by that material. Gluten feed, supplied by Corn Products Ltd, London, from Russian white maize, was the nearest product to maize bran that could be produced in the process of wet milling of maize. Its percentage proximate composition was, according to $\mathrm{Mr} \mathrm{A}$. L. Gaisford: moisture I2, protein $28 \cdot 5$, starch $17 \cdot 7$, oil $17 \cdot 7$, ash $3 \cdot 52$, and fibre $7 \cdot 0$. It contained $42 \cdot 1 \mu \mathrm{g}$ total nicotinic acid/g, $98 \%$ of it in bound form. One sample of gluten feed was treated in several batches with lime-water in one of two ways: $250 \mathrm{~g}$ gluten feed were heated with $600 \mathrm{ml}$ I $\%$ lime-water $\left(\mathrm{pH}\right.$ 10.0) for $9 \circ \mathrm{min}$ at $80^{\circ}$ (the $\mathrm{pH}$ of the suspension was 8.5 ) and left overnight; the $\mathrm{pH}$ was then brought to 6.8 with orthophosphoric acid, the material dried at $70^{\circ}$ and ground. A second sample was prepared in a similar way, but $0.1 \%$ lime-water was used. It can be seen (Table 3) that the first sample had only $20 \%$ of its total nicotinic acid in free form. The finding is in agreement with the observations mentioned earlier that treatment with lime-water does not necessarily liberate all the nicotinic acid. To obtain complete hydrolysis the material cooked with lime-water had to be exposed, while remaining alkaline, to further heating on a girdle. The second sample treated with $0.1 \%$ lime-water contained little or no free nicotinic acid; since the strength of lime-water was not enough to overcome the high acidity of the gluten feed $\left(\mathrm{pH}_{4}\right)$ the final $\mathrm{pH}$ was only $6 \cdot 0$. 


\section{Animals and diets}

In four experiments sixty-eight weanling male rats, weighing $50-60 \mathrm{~g}$, were used, four in a group. Litter-mates were distributed at random between the various groups. The animals were housed in separate cages and given food and water to appetite. They were weighed twice a week, and the food intake was determined daily. The experiments were divided into two periods: in a preliminary period all the rats were given the diet, described by Harris \& Kodicek (1950), containing yellow maize meal (diet I, Table 4). After 17 days all the animals had ceased growing, and they were then put on the experiment proper in which they were given the experimental diets shown in Tables 4 and 5 for 28 days. The criteria were gain in weight, absolute and per $100 \mathrm{~g}$ food eaten.

Table 4. Percentage composition of diets

\begin{tabular}{|c|c|c|c|c|}
\hline Constituent & Diet I & Diet 2 & Diet 3 & Diet 4 \\
\hline Maize meal, yellow & $40 \cdot 0$ & - & $35 \cdot 0$ & $35^{\circ} \circ$ \\
\hline Maize preparation* & - & $40 \cdot 0$ & - & - \\
\hline Gluten feed, treated with $I \%$ lime-water & - & - & 10.5 & - \\
\hline Gluten feed, treated with $0.1 \%$ lime-water & - & - & - & $10 \cdot 0$ \\
\hline Casein, 'vitamin-free' (Genatosan Ltd) & 3.5 & $3 \cdot 5$ & 3.5 & $3 \cdot 5$ \\
\hline Sucrose & $51 \cdot 5$ & $51 \cdot 5$ & $46^{\circ}$ & $46 \cdot 5$ \\
\hline Cottonseed oil & $2 \cdot 0$ & $2 \cdot 0$ & $2 \cdot 0$ & $2 \cdot 0$ \\
\hline L-Cystine & O.I & 0.1 & $0 \cdot I$ & c: \\
\hline Minerals $\uparrow$ & 3.0 & 3.0 & 3.0 & 3.0 \\
\hline Vitaminst & + & + & + & + \\
\hline
\end{tabular}

* (Diet $2 a$ ) : Plate Argentinian yellow maize; (diet $2 b$ ) D.N.L. tortilla; (diet $2 c$ ) Mexican white maize; (diet 2d) Mexican tortilla; (diet 2 e) masa harina; (diet $2 f$ ) tortilla prepared from masa harina (cf. p. 421).

$\dagger$ Minerals, as used previously (Kodicek \& Carpenter, r950); vitamins B, A, D, E and $\mathrm{K}$ as used previously (Kodicek \& Carpenter, r950) except that nicotinic acid was omitted or added in amounts stated in the text.

Table 5. Content of nicotinic acid, tryptophan and protein in experimental diets

\begin{tabular}{|c|c|c|c|c|c|c|}
\hline \multirow[b]{2}{*}{ Diet } & \multirow[b]{2}{*}{ Description of diet } & \multicolumn{3}{|c|}{$\begin{array}{l}\text { Nicotinic acid } \\
(\mu \mathrm{g} / \mathrm{g})\end{array}$} & \multirow{2}{*}{$\begin{array}{c}\text { Tryptophan } \\
\text { (mg/g) }\end{array}$} & \multirow{2}{*}{$\begin{array}{l}\text { Crude } \\
\text { protein } \\
(\mathrm{mg} / \mathrm{g})\end{array}$} \\
\hline & & Free & Bound & Total & & \\
\hline I & Untreated maize & 0.24 & $7 \cdot 56$ & $7 \cdot 80$ & 0.72 & 66 \\
\hline $2 a$ & Untreated Argentinian maize & 0.24 & $7 \cdot 20$ & $7 \cdot 44$ & 0.85 & 66 \\
\hline$z b$ & D.N.L. tortilla & 6.64 & 0 & $6 \cdot 64$ & 0.85 & 66 \\
\hline $2 c$ & Untreated Mexican maize & 0.24 & $5 \cdot 76$ & $6 \cdot 00$ & 0.82 & 73 \\
\hline $2 d$ & Mexican tortilla & 3.92 & 0 & 3.92 & 0.85 & 73 \\
\hline $2 e$ & Masa harina & 0.52 & $4 \cdot 76$ & $5 \cdot 28$ & 0.88 & 67 \\
\hline $2 f$ & Tortilla from masa harina & $\mathrm{I} \cdot 32$ & $4 \cdot 36$ & 5.68 & 0.88 & 67 \\
\hline 3 & Gluten feed, treated with I $\%$ lime-water & $1 \cdot 12$ & $10 \cdot 14$ & $11 \cdot 26$ & 0.80 & $9 \mathrm{I}$ \\
\hline 4 & Gluten feed, treated with $0.1 \%$ lime-water & 0.29 & 10.04 & 10.33 & 0.80 & 91 \\
\hline
\end{tabular}

Diet $2 d$ was supplemented with $5 \mathrm{mg}$ nicotinic acid/ $\mathrm{kg}$ and diets $2 a, 2 c$ and $2 f$ with $10 \mathrm{mg}$ nicotinic acid $/ \mathrm{kg}$ for rats serving as positive controls.

In Expt $\mathrm{I}$, rats in group 3 were given a diet with D.N.L. tortilla (diet $2 b$ ); rats in group I served as deficient controls ( $\operatorname{diet} 2 a$ ) and those in group 2 were positive controls, receiving diet $2 a$ supplemented with $10 \mathrm{mg}$ nicotinic acid/kg diet.

In Expt 2, rats in group 6 were given a diet with Mexican tortilla (diet 2d); rats in 
group 7 received the same diet supplemented with $5 \mathrm{mg}$ nicotinic acid/kg diet; rats in group 4 served as deficient controls (diet $2 c$ ) and those in group 5 as positive controls, receiving a supplement of nicotinic acid, Io $\mathrm{mg} / \mathrm{kg}$ diet $2 c$.

In Expt 3, rats in group 9 received a diet with masa harina (diet $2 e$ ); rats in groups Io and I I received a diet with masa harina baked into tortilla (diet $2 f$ ) unsupplemented or supplemented with Io mg nicotinic acid/kg diet. Rats in group 8 served as deficient controls and received a diet with yellow-maize meal (diet $\mathrm{I}$ ), since there was not enough of the maize from which the masa harina had been prepared to supply this group.

In Expt 4, rats in group I 5 received a diet with $10.5 \%$ gluten feed treated with $\mathrm{I} \%$ lime-water, but neutralized before drying (diet 3); rats in group I 6 received the same diet supplemented with to mg nicotinic acid $/ \mathrm{kg}$ diet, and those in group 17 received I0 $\%$ gluten feed hydrolysed with only $0.1 \%$ lime-water and neutralized before drying (diet 4 ). Rats in group 12 were deficient controls, and the animals in groups I3 and $\mathrm{I}_{4}$ were positive controls, each given daily by mouth $5^{\circ}$ or $25^{\circ} \mu \mathrm{g}$ nicotinic acid dissolved in $0.5 \mathrm{ml}$ water.

RESULTS

\section{Nutrients in diets}

Values for bound and free nicotinic acid, tryptophan and crude protein in the experimental diets are given in Table 5 . It can be seen that the diets containing untreated maize had only a negligible amount of free nicotinic acid which was derived from casein and maize germ. The diets containing gluten feed treated with lime-water, masa harina or tortilla baked from it, also contained a relatively small amount of free nicotinic acid, but in the other two tortilla diets (diets $2 b$ and $2 d$ ) all the nicotinic acid was present in free form.

\section{Tests with rats}

Table 6 shows the average performance of the rats during the experiment proper in terms of weekly weight gain and weight gain per roo g food eaten, as well as daily intake of food, free and bound nicotinic acid and tryptophan. The mean growth curves of the various groups of rats are plotted in Fig. I. None of the rats serving as deficient controls (groups nos. I, 4, 8 and I2) recovered from the deficiency, and several died within $2-3 \frac{1}{2}$ weeks. The positive control animals in groups nos. 2, 5, 7, I I, 13, 14 and I6 given nicotinic-acid supplements throve well. The rats given the tortilla diets (groups nos. 3 and 6) grew well. On the other hand, animals receiving diets in which only small amounts of free nicotinic acid were present gained little or lost weight (groups nos. 9, IO, 15 and 17 ). The rats in group ${ }_{5} 5$, given a diet containing gluten feed treated with lime-water in which only one-fifth of the total nicotinic acid was in free form, received so little of the vitamin that they remained deficient and three died during the experiment. Comparison of the rats' performance, with their intake of free and total nicotinic acid, makes it evident that the improvement was related to the consumption of free nicotinic acid and not of the bound form. Thus, although the amount of bound nicotinic acid taken by the deficient rats was equal to the amount of free nicotinic acid taken by the animals receiving tortilla diets (groups nos. 3 and 6), it had no curative effect. 


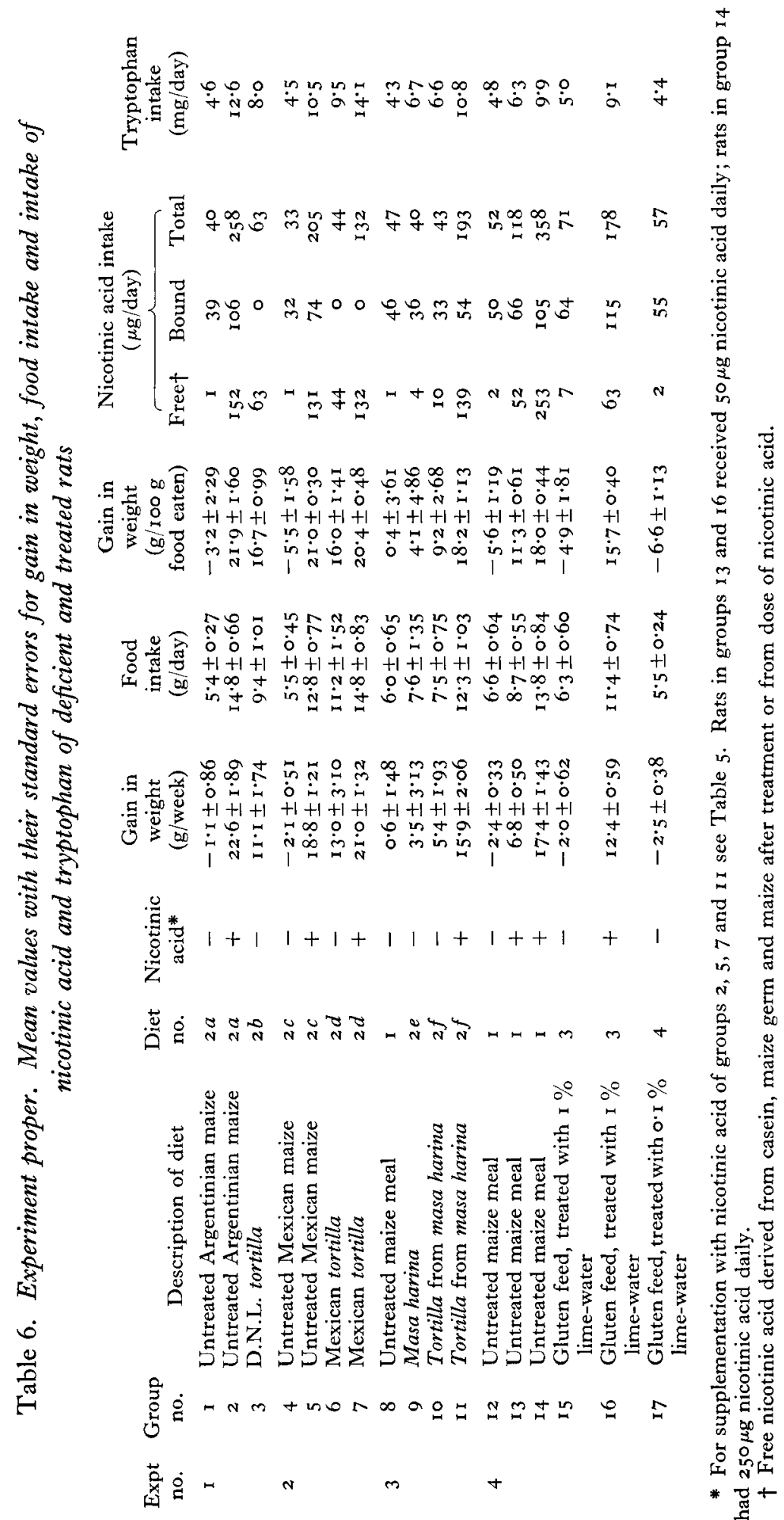


In Fig. 2 scatter diagrams for all the rats show the relation of the weekly weight gain to the logarithm of the amount of free or total nicotinic acid taken. Regression lines were fitted for both from the equations: for free nicotinic acid, $y=-3 \cdot 78+9 \cdot 63 x$; for total nicotinic acid, $y=-34 \cdot 12+21 \cdot 88 x$. The correlation coefficient between

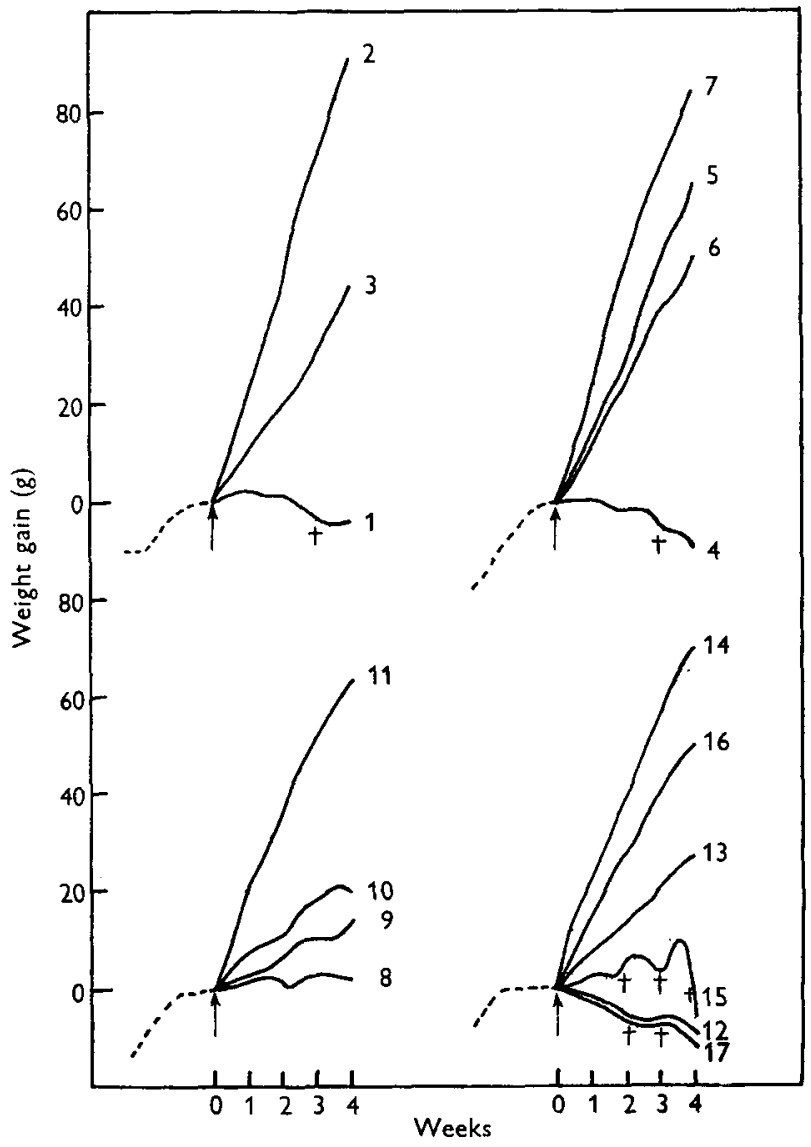

Fig. I. Mean growth curves of rats given various treatments in four experiments. The numbers are the group numbers as given in Table 6 : groups $1,4,8$ and 12 were deficient control rats; groups 2 , 5, I $_{3}$ and 14 were positive control rats given a supplement of nicotinic acid; group 3 received the D.N.L. tortilla diet; group 6 the Mexican tortilla diet; group 7 the Mexican tortilla diet with a supplement of nicotinic acid; group 9 the masa harina diet; group ro the diet of tortilla made from masa harina; group I I the same diet as group io but supplemented with nicotinic acid; group I5 the diet containing gluten feed treated with I \% lime-water; group i 6 the same diet supplemented with nicotinic acid; group 17 the diet containing gluten feed treated with $0.1 \%$ lime-water. -.-, preliminary period; - , experiment proper; $\uparrow$, beginning of experiment proper; $\uparrow$, died.

the weight gain and logarithm of amount taken was for free nicotinic acid $0.9 \circ$, but was less, $0 \cdot 79$, for total nicotinic acid. The difference between the two correlation coefficients was significant $(0.01<P<0.02)$. It can be seen from Fig. 2 that with a daily intake of from 30 to $80 \mu \mathrm{g}$ total nicotinic acid, the weekly weight gain varied from nil to as much as $16 \mathrm{~g}$. As expected, the correlation coefficient between the weight gain and the logarithm of the amount of food taken was high, 0.94 . 

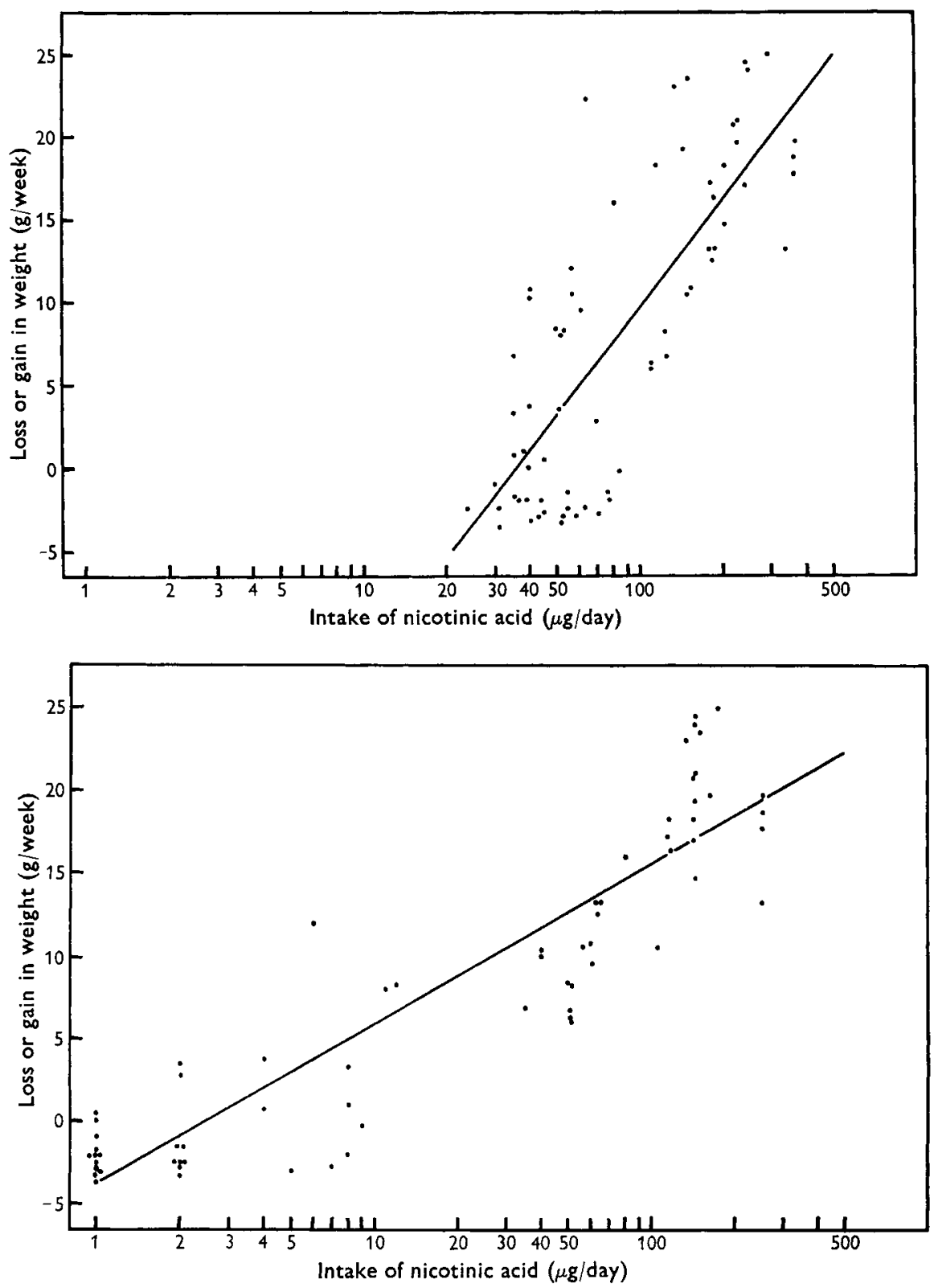

Fig. 2. Scatter diagrams showing relationship between the logarithm of amount of nicotinic acid taken and the weight gain in individual rats. Upper half: intake of total nicotinic acid. Lower half: intake of free, available nicotinic acid. Straight lines, fitted regression lines.

\section{Nicotinic-acid content of beverages}

Although the liberation of free nicotinic acid satisfactorily explains the curative effect of maize treated with lime-water for rats, and may play an important part in the low incidence of pellagra in areas where such maize is consumed, there may yet be some other factors that influence the nicotinic-acid status of the population. Krehl 
(1949) suggested that the traditional Mexican drink pulque prepared from the fermented sap of the Agave tree contains nicotinic acid and that a sufficient amount of it could contribute significantly to the daily requirement for the vitamin. We have examined pulque for nicotinic acid and found all of it in free, available form (Table 7). For comparison the results are given for Kaffir beer, in which only a portion of the total nicotinic acid is free, presumably the part derived from the yeast in the freshly fermented brew, as referred to by Platt \& Webb (1946). No liberation of bound nicotinic acid occurs in the fermentation of English beer (Table 7).

\section{Table 7. Nicotinic-acid content of beverages}

\begin{tabular}{|c|c|c|c|c|}
\hline \multirow[b]{3}{*}{ Beverage* } & \multicolumn{4}{|c|}{ Nicotinic acid $(\mathrm{mg} / \mathrm{I} 00 \mathrm{ml})$} \\
\hline & \multirow{2}{*}{$\begin{array}{l}\text { Unhydrolysed } \\
\text { extract. } \\
\text { Microbiological } \\
\text { test }\end{array}$} & \multicolumn{3}{|c|}{$\begin{array}{l}\text { Hydrolysed extract } \\
\text { (total nicotinic acid) }\end{array}$} \\
\hline & & $\begin{array}{c}\text { Microbiological } \\
\text { test }\end{array}$ & $\begin{array}{l}\text { Chemical } \\
\text { test }\end{array}$ & Mean \\
\hline Pulque & 0.40 & 0.43 & 0.46 & 0.431 \\
\hline Kaffir beer (pito) & 0.20 & 0.35 & 0.33 & 0.34 \\
\hline Beer, Guinness & 0.13 & 0.77 & 0.97 & 0.87 \\
\hline
\end{tabular}

* Pulque, from Mexico, $3 \%$ solids, fermented sap of Agave tree. Pito, native Kaffir beer, freshly fermented from maize, from Dr F. C. Roger, Nigeria. Beer (Arthur Guinness, Son and Co. Ltd), spray-dried, ether-extracted; measurements done on this material were recalculated for liquid beer containing $5.8 \mathrm{~g}$ solids/100 ml. Paper chromatographic assay showed that all the nicotinic acid was in bound form.

+ Mean value for unhydrolysed and hydrolysed extracts; all nicotinic acid in the free form.

\section{DISCUSSION}

The results of our experiments show that several factors may contribute to the successful liberation of bound nicotinic acid in maize. The concentration of the lime-water must be sufficiently high to overcome the natural acidity of the maize, and sufficient time must elapse for the alkaline solution to penetrate into the kernels and exercise its hydrolysing effect. Even then all the bound nicotinic acid may not be liberated, and further heating at alkaline $\mathrm{pH}$ during baking is necessary to complete the process in tortilla. With excessive washing not only is a greater proportion of the nicotinic acid lost, but also the alkalinity is decreased, with less hydrolysis subsequently on baking. According to Cravioto (1956), in some parts of Mexico the maize grain, cooked with lime-water, is washed lightly two or three times, but in Mexico City the grain is not so washed at all. Such apparently slight differences in preparation may result in greatly different final products whose free nicotinic-acid content may differ considerably. It appears, therefore, essential that experimenters should describe in detail how any limewater treatment was done, state the $\mathrm{pH}$ of their material and, if possible, estimate its free nicotinic-acid content.

Our results confirm the findings with pigs (Kodicek et al. 1959) and rats (Laguna \& Carpenter, 195 ; Pearson et al. 1957; Harper et al. 1958) that the liberation of free nicotinic acid in maize appears to be the main factor responsible for the curative effect on nicotinic-acid deficiency of maize treated with lime-water. 
'There is, however, the possibility that some 'unconsidered trifles in the diet' (Drummond \& Moran, 1944) might contribute to the supply of available nicotinic acid. Thus pulque, a native Mexican drink, might be a good source of the vitamin. Coffee beans also are a good source of available nicotinic acid, having about ${ }_{108-144}$ $\mu \mathrm{g}$ nicotinic acid/g, all in available form (Kodicek, I942). On the other hand beer, which according to Drummond \& Moran (1944) contains as much as $1.5 \mathrm{mg}$ nicotinic $\mathrm{acid} / \mathrm{roo} \mathrm{ml}$, has the vitamin in unavailable, bound form, as already observed by Coates, Ford, Harrison, Kon, Shepheard \& Wilby (1952).

It will be noticed that the curative effect of free nicotinic acid increases the food consumption of experimental animals and, consequently, the tryptophan intake rises. It is relevant to ask how much nicotinic acid the increased tryptophan intake contributes by conversion of the amino acid into the vitamin. The high correlation coefficient between the intake of free nicotinic acid and the weight gain of our rats suggests that the contribution of dietary tryptophan was small. That view is supported by the findings of Krehl, Sarma \& Elvehjem (I946), which established that for rats $0 \cdot$ I-O. I $5 \%$ tryptophan in the diet is necessary for protein requirements as a source of nitrogen. Oesterling \& Rose (1952) found with $0.125 \%$ tryptophan in the diet no apparent conversion of tryptophan into the vitamin, and with $0.15 \%$ the quantity of tryptophan transformed must have been small. Similarly, Salmon (1954) found that in diets containing $40 \%$ maize and $9 \%$ protein the rat needed, to cover its growth requirement, at least $0.1 \%$ tryptophan in presence of an adequate amount of nicotinic acid. Our diets contained only $0.07-0.09 \%$ tryptophan and thus supplied no excess of tryptophan for conversion into the vitamin.

\section{SUMMARY}

I. In four experiments, sixty-eight weanling male rats were given, for 17 days, a diet containing $40 \%$ maize, so that they developed a deficiency of nicotinic acid. After that time four rats in each of six groups were given diets in which the maize was replaced by maize preparations treated in various ways with lime-water. Rats in two of the six groups were given diets with tortilla prepared according to the Mexican recipe in Cambridge, or in Mexico. In these two tortilla preparations all the nicotinic acid had been released from its bound form. Rats in the other four of the six groups were given diets containing maize preparations treated with lime-water in such a way that little or no bound nicotinic acid was liberated. Rats in the remaining eleven groups served as deficient or nicotinic-acid supplemented controls.

2. Only those maize preparations in which all the bound nicotinic acid had been liberated were capable of curing the deficient rats as completely as supplements of nicotinic acid.

3. For efficient liberation of nicotinic acid from its bound form in maize by treatment with lime-water, strict adherence to the original Mexican recipe was found essential. In certain conditions only partial hydrolysis of the bound form occurred during the cooking of maize kernels with lime-water, and the liberation was completed during subsequent baking of the alkaline maize mash to tortilla.

4. Attention is drawn to the possibility that certain small items in the diet, 
such as native drinks, may contribute significantly to the supply of free, available nicotinic acid.

We wish to thank Mr A. L. Gaisford and Mr G. H. Gunn of Corn Products Ltd, London, for their generous supply of gluten feed and Dr R. W. Carroll of The Quaker Oats Co., Chicago, for the gift of masa harina flour. We are particularly grateful to Dr R. O. Cravioto for the large sample of Mexican maize, tortilla and dehydrated pulque and to Dr W. J. Stringer, of Arthur Guinness, Son and Co, Dublin, for the sample of spray-dried beer. We wish to thank also Dr F. C. Rodger, Director of the West African Ophthalmic Service, for the sample of freshly fermented Nigerian Kaffir beer (pito).

Note added 8 May I959. Since this paper was prepared, Squibb, Braham, Arroyave \& Scrimshaw (1959) have pointed out the importance of the consumption of other food constituents or beverages, such as beans and coffee, in the prevention of pellagra in Central America.

\section{REFERENCES}

Chaudhuri, D. K. \& Kodicek, E. (I950), Biochem. F. 47, xxxiv.

Clegg, K. M., Kodicek, E. \& Mistry, S. P. (1952). Biochem. F. 50, 326.

Coates, M. E., Ford, J. E., Harrison, G. F., Kon, S. K., Shepheard, E. E. \& Wilby, F. W. (r952). Brit. F. Nutr. 6, 75 .

Cravioto, O. Y., Cravioto, R. O., Huerta, R. O., Guzmán, J. G., Massieu, G. H. \& Calvo de la Torre, J. (1950). Ciencia, Méx., ro, I45.

Cravioto, R. O. (1956). Private communication.

Cravioto, R. O., Anderson, R. K., Lockhart, E. E., Miranda, F. de P. \& Harris, R. S. (1945). Science, I02, $9 \mathrm{I}$.

Cravioto, R. O., Massieu, G. H., Cravioto, O. Y. \& Figueroa, F. de M. (1952). F. Nutr. 48, 453.

Drummond, J. C. \& Moran, T. (1944). Nature, Lond., 153, 99.

Fiorentini, M., Gaddi, A. M. \& Bonomolo, A. (1956). Boll. Soc. ital. Biol. sper. 32, 793.

Goldsmith, G. A., Gibbens, J., Unglaub, W. G. \& Miller, O. N. (1956). Amer. F. clin. Nutr. 4, I5 I.

Goldsmith, G. A., Rosenthal, H. L., Gibbens, J. \& Unglaub, W. G. (1955). F. Nutr. 56, 37 I.

Graham, C. E., Smith, E. P., Hier, S. W. \& Klein, D. (1947). F. biol. Chem. 168, 7 I I.

Harper, A. E., Punekar, B. D. \& Elvehjem, C. A. (1958). F. Nutr. 66, I63.

Harris, L. J. \& Kodicek, E. (1950). Brit. F. Nutr. 4, xiii.

Heathcote, J. G., Hinton, J. J. C. \& Shaw, B. (I952). Proc. roy. Soc. B, 139, 276.

Kodicek, E. (1942). Biochemical studies on nicotinic acid. Ph.D. Thesis: University of Cambridge.

Kodicek, E. (I95I). Biochem. $¥ .48$, viii.

Kodicek, E., Braude, R., Kon, S. K. \& Mitchell, K. G. (1956). Brit. F. Nutr. Io, 5 I.

Kodicek, E., Braude, R., Kon, S. K. \& Mitchell, K. G. (1959). Brit. F. Nutr. 13, 363 .

Kodicek, E. \& Carpenter, K. J. (1950). Blood, 6, 522.

Kodicek, E. \& Pepper, C. R. (1948). F. gen. Microbiol. 2, 306.

Kodicek, E. \& Reddi, K. K. (1951). Nature, Lond,, 168, 475.

Krehl, W. A. (1949). Vitam. E Horm. 7, 1 I I.

Krehl, W. A., Henderson, L. M., de la Huerga, J. \& Elvehjem, C. A. (1946). F. biol. Chem. 166, 53 I.

Krehl, W. A., Sarma, P. S. \& Elvehjem, C. A. (1946). F. biol. Chem. 162, 403.

Laguna, J. \& Carpenter, K. J. (I95I). F. Nutr. 45, 21.

Massieu, G. H., Cravioto, O. Y., Cravioto, R. O., Guzmán, G. \& Suarez Soto, G. Y. M. de L. (I956). Ciencia, Méx., I6, 24.

Oesterling, M. J. \& Rose, W. C. (1952). F. biol. Chem. 196, 33.

Pearson, W. N., Stempfel, S. J., Valenzuela, J. S., Utley, M. H. \& Darby, W. J. (1957). F. Nutr. 62, 445.

Platt, B. S. \& Webb, R. A. (1946). Proc. Nutr. Soc. 4, 132.

Reddi, K. K. \& Kodicek, E. (I953). Biochem. F. 53, 286.

Salmon, W. D. (1954). Arch. Biochem. Biophys. 5I, 3 o.

Squibb, R. L., Braham, J. E., Arroyave, G. \& Scrimshaw, N. S. (I955). Fed. Proc. 14, 32.

Squibb, R. L., Braham, J. E., Arroyave, G. \& Scrimshaw, N. S. (I959). F. Nutr. 67, 35 I.

Wang, Y. L. \& Kodicek, E. (1943). Biochem. F. 37, 53 o. 